\title{
Phytochemicals, acute toxicity and in-vitro antioxidant activity of ethanol extract of Sphenocentrum jollyanum leaves
}

\author{
Emmanuel Uka ${ }^{1 *}$, Oboso E. Etim ${ }^{1}$, Akaninyene O. Effiong ${ }^{1}$ and Imoh E. Jacobs ${ }^{2}$ \\ ${ }^{1}$ Department of Biochemistry, University of Uyo, Nigeria. \\ ${ }^{2}$ Department of Pharmacognosy and Natural Medicine, University of Uyo, Nigeria. \\ *Corresponding author. Email: emmanueluka@uniuyo.edu.ng
}

Copyright @ 2020 Uka et al. This article remains permanently open access under the terms of the Creative Commons Attribution License 4.0, which permits unrestricted use, distribution, and reproduction in any medium, provided the original work is properly cited.

Received 24th May, 2020; Accepted 29th June, 2020

\begin{abstract}
Medicinal plants possess strong antioxidants that help to scavenge and protect the human health against several diseases caused by free radicals. This study was carried out to evaluate the phytochemical constituents, acute toxicity and antioxidant activity of the ethanol extract of Sphenocentrum jollyanum leaves in order to validate the medicinal potential of this herb. The antioxidant activity was evaluated using different in vitro models such as total phenolic, flavonoid content, DPPH radical scavenging activity, ferric reducing antioxidant power (FRAP) and Iron chelating activity. Phytochemical constituents included alkaloids, saponins, tannins, flavonoids and cardiac glycosides while total phenolic, flavonoid and gallic acid equivalent were $31.49,29.98$ and $1215.80 \mathrm{mg} / \mathrm{mL}$ respectively. The acute toxicity revealed that the oral lethal dose of the ethanol extract of $S$. jollyanum leaves is non-toxic and safe for consumption. The leaf extract of S. jollyanum exhibited scavenging activity with $\mathrm{IC}_{50}$ of $164.214,72.410$ and $167.202 \mathrm{mg} / \mathrm{mL}$ for DPPH, FRAP and Iron chelating activity respectively. The results obtained from this study reveal that the extract is rich in antioxidant components with several mechanisms of eliciting antioxidant actions which provide a scientific basis for its use in traditional system of medicine.
\end{abstract}

Keywords: Acute toxicity, antioxidant, medicinal plants, phytochemical, Sphenocentrum jollyanum.

\section{INTRODUCTION}

Medicinal plants have been used by mankind for millennia; their use is as old as humanity itself. The range of species used and their scope for healing is vast. Cures as yet undiscovered may exist in plants as yet undescribed. Currently, it is estimated that the number of higher plant species used worldwide for medicinal purposes is more than 50,000 (Schippmann et al., 2002). In fact, ancient man was totally dependent on plants for his needs of treatment, prevention and other form of medicaments. Preparations from medicinal plants are a rich source of novel drugs that forms the ingredients in traditional systems of medicine, such as in modern medicines, nutraceuticals, food supplements, folk medicines, pharmaceuticals intermediate bioactive principles and lead compounds in synthetic drugs (Nayak et al., 2010). Available evidence suggests that thirty percent of all modern drugs are produced from plants (Burns, 2000). The World Health Organization (WHO) also reported that $80 \%$ of the world's population are using some type of natural or herbal treatment for their health care need (Sandhya et al., 2006; Topno and Sinha, 2018).

Globally, the employment of medicinal plants as a substitute for orthodox drugs in the management of various diseases has been increasing majorly due to the low-affordability of modern health facilities. Other reasons could be attributed to the relative availability of medicinal herbs, poverty, and recent revelations that they possess active compounds that may be responsible for different biological and pharmacological actions (Tiwari and Mehta, 2013). Furthermore, recent revelations highlight that they possess active compounds that may be responsible for different biological and pharmacological actions (Tiwari 
and Mehta, 2013).

The world health organization (WHO) defines "traditional medicine as the total of all knowledge and practices (whether explicable or not) used in the diagnosis, prevention and elimination of the physical, mental, and social imbalance and relying exclusively on the practical experience and observations handed down from generation to generation whether verbally or orally or in writing" (WHO, 2013). One of the most important medicinal plants, which are widely used in the traditional system of medicine is Sphenocentrum jollyanum.

$S$. Jollyanum is a plant that belongs to the family, Menispermaceae. It is a small erect sparsely branched shrub, growing up to $1.5 \mathrm{~m}$ in height with very few branches and glabrous leaves up to $20 \mathrm{~cm}$ in length with the breath of 5 to $12 \mathrm{~cm}$. It is widely distributed in Ghana, Cote d' Ivoire, Sierra Leone, Cameroon and Nigeria. It is known locally in Nigeria as Oji-enyi, Ajo or Akerejupon and Ibong Isong among the Igbos, Yorubas and the Ibibios respectively (Nia et al., 2004). The plant is also known as Aduro kokoo (red medicine) or Okramankote (dog's penis) and "Krakoo" among the Akan and Asante tribes of Ghana (Amidu et al., 2008; Amidu, 2008). S. jollyanum has antihypertensive, antioxidant, anti-nociceptive, antiviral and anti-angiogenic effects in animals (Nia et al., 2004). Irvine (1961) and Abbiw (1990) also reported the aphrodisiac and Central Nervous System (CNS) stimulant effects when chewed or taken in alcoholic bitters respectively. It is also believed to be emetic and purgative, especially when poisoning is suspected. The sap is believed to relieve stomach ache, constipation, boost appetite and sexual drive (Muko et al., 1998)

The plant has also been documented for its use against chronic coughs, worms and other inflammatory conditions as well as tumours (Kayode et al., 2009). It is also reported that the pounded roots are effective in blood-glucoselowering potential in hyperglycemic and alloxan-induced diabetic rabbits while the boiled roots are given against epilepsy in Cote d' Ivoire and Ghana respectively (OliverBever, 1986; Mbaka et al., 2009).

Despite the abundant literature on the phytochemical constituents and ethnobotanical use of medicinal plants, there is limited documented scientific evidence to support the antioxidant potential of $S$. Jollyanum. This research was designed to study the ethanol extract of $S$. Jollyanum leaves on the phytochemical constituents, acute toxicity and in vitro antioxidant activities.

\section{MATERIALS AND METHODS}

\section{Collection, authentication and preparation of plant extract}

Fresh, matured and whole leaves of Sphenocentrum jollyanum were harvested from Aka in Ibiono Ibom Local
Government Area of Akwa lbom State, Nigeria. The plant was identified and authenticated by a taxonomist in the Department of Pharmacognosy and Natural Medicine, University of Uyo, Akwa Ibom State. The voucher specimen (NUUH:040/15) was deposited at the herbarium. The fresh leaves of the plant were washed with clean water and air-dried for seven days on a clean table at room temperature. The dried leaves were cut and pulverized, using mortar and pestle.

About $833.7 \mathrm{~g}$ of pulverized $S$. jollyanum leaves were macerated in $60 \%$ ethanol and allowed to stand for 72 hours with intermittent stirring to ensure that the solvent extract the active ingredients. The mixture was filtered using a glass funnel laid with a filter paper into a two-litre beaker and concentrated in a water bath set (Searl instruments, staewell, England) at $45^{\circ} \mathrm{C}$. The paste-like gel extract obtained was further dried in a desiccator between 28 to $33^{\circ} \mathrm{C}$ to eliminate any remaining water content in the extract. It was then transferred into pre-weighed transparent containers, weighed and stored in the refrigerator at $4^{\circ} \mathrm{C}$ before use. The percentage yield of $S$. Jollyanum extract was $22.6 \%$.

\section{Ethics}

This study was conducted according to standard protocols of the National Institute of Health $(\mathrm{NIH}, 2015)$ guidelines for use and care of laboratory animals and experiments were in accordance with CPCSEA ethical guidelines.

\section{Phytochemical screening}

The phytochemical screening of ethanol extract of $S$. jollyanum (SP) leaves was determined using the methods of Harborne (2005).

\section{Test for alkaloids}

About $0.5 \mathrm{~g}$ of the extract was weighed into a beaker in triplicate. $1 \mathrm{~mL}$ of $5 \% \mathrm{HCl}$ was added and warmed in a water bath for a few minutes and filtered. To $1 \mathrm{ml}$ of the filtrate were treated with a few drops of Dragendoff's reagent, Meyer's reagent, and Hager's reagent respectively. The appearance of orange, cream, and yellow precipitates for Dragendoff's reagent, Meyer's reagent, and Hager's reagent respectively confirm positive results. Instead, green, light brown and no yellow precipitates respectively appeared.

\section{Test for saponins (Frothing test)}

About $0.5 \mathrm{~g}$ of the plant extract was dissolved in $2 \mathrm{~mL}$ 
distilled water. The solution was shaken vigorously for one minute in a test tube until froth appeared. The test tube was placed in a hot water bath to observe for persistent frothing. The appearance of foam or froth that persisted was taken as preliminary evidence for the presence of saponins

\section{Test for tannins (Ferric chloride test)}

About $10 \mathrm{~mL}$ of distilled water was added in $0.5 \mathrm{~g}$ of leaf extracts in a test tube and stirred. The solution was then filtered and $5 \%$ ferric chloride was added to the filtrate. The formation of a blue-black, green or blue-green precipitate indicated the presence of tannins.

\section{Test for phlobatannins (Hydrochloric acid test)}

About $0.5 \mathrm{~g}$ of the leaf extract was boiled with $1 \mathrm{~mL}$ of $1 \%$ hydrochloric acid $(\mathrm{HCl})$. Deposition of red coloured precipitate indicated a positive test.

\section{Test for flavonoids}

About $0.5 \mathrm{~g}$ of the leaf extract was dissolved in $2 \mathrm{~mL}$ of methanol solution. The solution was warmed and pieces of magnesium ribbon were added to this solution and 5 to 6 drops of the Con. $\mathrm{HCl}$ acid was added. The formation of effervescences and orange, red, crimson or magneta colour indicated the presence of flavonoids.

\section{Test for cardiac glycosides}

About $0.5 \mathrm{~g}$ of the extract was dissolved in $2 \mathrm{~mL}$ of chloroform. Running down the side of the tube, few drops of concentrated sulphuric acid were carefully added to form a lower layer. A reddish-brown colour at the interface indicated the presence of cardiac glycosides.

\section{Acute toxicity study}

The acute toxicity study was determined by the method described by Lorke, (1983). Animals were fasted overnight and LD50 evaluation was carried out in two phases intraperitoneally (i.p) at all the doses. In the first phase, nine rats were randomly placed into three groups of three mice each. Groups I, II and III were treated with the extract at doses of 1000,2000 and $3000 \mathrm{mg} / \mathrm{kg}$ body weight $(\mathrm{mg} / \mathrm{kgbw})$ orally respectively. The second phase design was determined by the result obtained from the first phase. In the second phase, nine mice were put into three groups of three mice each. Groups I, II and III were administered the extract at doses 3500,4500 and $5000 \mathrm{mg} / \mathrm{kg}$ body weight respectively. In both phases, the mice were also observed for 24 hours for signs of toxicity and mortality. The $\mathrm{LD}_{50}$ value was then calculated as the geometric mean of the highest non-lethal dose (with no death) and the lowest lethal dose (where death occurred). Additionally, the third group of three mice was set up as a control group fed with normal feed and water only intraperitoneal.

\section{Evaluation of antioxidant activity by in vitro techniques}

\section{1, 1-diphenyl-2-picrylhydrazyl (DPPH) free radical scavenging assay}

1, 1-diphenyl-2-picrylhydrazyl (DPPH) radical scavenging capacity of the ethanol leaf extract was determined according to the modified method described by Repon et al. (2013). About $450 \mu \mathrm{L}$ of $50 \mathrm{mmol} / \mathrm{l}$ Tris-HCl buffer $(\mathrm{pH}$ 7.4) was mixed with solutions of the extract and ascorbic acid (standard) at different concentrations $(0.1,0.2,0.3$, 0.4 and $0.5 \mathrm{mg} / \mathrm{mL}$ ), followed by the addition of $2 \mathrm{ml}$ of 0.1 $\mathrm{mmol} / \mathrm{L}$ DPPH-methanol solution. The mixture was swirled and kept in the dark for 15 minutes incubation time with a colour change from purple to yellow. Absorbance was measured at $517 \mathrm{~nm}$ using a mixture of distilled water, buffer and methanol as blank. The DPPH radical scavenging activity was calculated using the following equation:

DPPH scavenging effect $(\%)=\frac{\mathrm{Ac}-\mathrm{As}}{\mathrm{Ac}} \times 100$

Where Ac is the absorbance of the control and As is the absorbance of test samples or standard sample (ascorbic acid). The concentration of extract of which $50 \%$ inhibition is observed $\left(\mathrm{IC}_{50}\right)$ is calculated in $\mathrm{mg} / \mathrm{ml}$.

\section{Determination of the total phenolic content}

The total phenolic content (TPC) of $S$. jollyanum leaves extract was assessed using the Folin-Ciocalteau method as previously described (Lee et al., 2015) with slight modification. A $0.5 \mathrm{Ml}$ of the extract was mixed with $2.5 \mathrm{~mL}$ of $10 \%$ Folin-Ciocalteu reagent. After 5 minutes, $2 \mathrm{~mL}$ of $20 \% \mathrm{Na}_{2} \mathrm{CO}_{3}$ solutions were subsequently added to the mixture and incubated at $40^{\circ} \mathrm{C}$ for 10 minutes with intermittent agitation. Afterwards, the sample was cooled and the absorbance was measured utilizing a UV/VIS Spectrophotometer (model $752 \mathrm{UK}$ ) at $765 \mathrm{~nm}$ against a blank without extract. The TPC of the samples were obtained by comparing the absorbance with that of standard gallic acid calibration curve, and expressed as milligram of gallic acid equivalent per gram ( $\mathrm{mg} \mathrm{GAE} / \mathrm{g}$ ) of dry weight of the extracts. 


\section{Determination of the total flavonoid content}

The total flavonoid content was measured using aluminium chloride colourimetric method (Zhishen et al., 1999) with slight modification. Gallic acid was used as a standard to plot the calibration curve. Varying concentrations of the leaf extract of $S$. jollyanum ranging from $0.1,0.2,0.3,0.4$ and $0.5 \mathrm{mg} / \mathrm{mL}$ were prepared. Then, $2.5 \mathrm{~mL}$ of each concentration was measured into five distinct test tubes. $1.5 \mathrm{ml}$ of $5 \%$ Sodium Nitrite solution was added to each test tube. Then, $1.5 \mathrm{~mL}$ of aluminum chloride was added, shaken and left to incubate for 10 minutes after which, 2 $\mathrm{mL}$ of $4 \% \mathrm{NaOH}$ was added to each test tube and incubated for 15 minutes. The absorbance readings were recorded at $510 \mathrm{~nm}$ UV-visible spectrophotometer. The total flavonoid content was expressed as $\mathrm{mg} / \mathrm{g}$ of gallic acid equivalents in milligrams per gram (mg GE/g) of extract.

\section{Determination of ferric reducing antioxidant power (FRAP) activity}

The ferric $(\mathrm{Fe} 3+)$ reducing power of the ethanol leaf extract of $S$. jollyanum was determined using the modified $\mathrm{Fe}^{3+}$ to $\mathrm{Fe}^{2+}$ reduction assay with minor modifications ( $\mathrm{Hu}$ et al., 2016). Various concentrations $(0.1,0.2,0.3,0.4$ and 0.5 $\mathrm{mg} / \mathrm{mL})$ of the leaf extract and ascorbic acid $(2.5 \mathrm{ml})$ were mixed individually with the mixture containing $2.5 \mathrm{ml}$ of $2 \%$ sodium phosphate buffer ( $\mathrm{pH} \mathrm{6.6)}$ and $2.5 \mathrm{ml}$ of potassium ferricyanide $\left(\mathrm{K}_{3} \mathrm{Fe}(\mathrm{CN})_{6}\right)(1 \% \mathrm{w} / \mathrm{v})$. The resulting mixture was incubated at $50^{\circ} \mathrm{C}$ in a water bath for 20 minutes, to reduce ferricyanide into ferrocyanide. The reaction was stopped by adding $2.5 \mathrm{~mL}$ of trichloroacetic acid $(10 \% \mathrm{w} / \mathrm{v})$. The resulting mixture was centrifuged at $3000 \mathrm{rpm}$ for 10 minutes. Finally, the supernatant of the solution $(2.5 \mathrm{~mL})$ was mixed with $2.5 \mathrm{~mL}$ of distilled water and $0.5 \mathrm{~mL}$ of $0.1 \%$ ferric chloride solution. The reaction mixture was left to stand for 10 minutes and the Perl's Prussian blue colour was measured at $700 \mathrm{~nm}$ against a blank. Increased absorbance of the reaction mixture indicated greater reducing power.

\section{Evaluation of Iron (II) chelating activity}

The $\mathrm{Fe}^{2+}$ chelation was estimated using the protocol described by Dinis et al. (1994). About $0.2 \mathrm{~g}$ of leaf extract was serially diluted with $200 \mathrm{~mL}$ of distilled water to concentrations of $0.1,0.2,0.3,0.4$ and $0.5 \mathrm{mg} / \mathrm{mL}$ respectively. $2 \mathrm{~mL}$ of the serially diluted extract was added to $1 \mathrm{~mL}$ of phenanthroline as well as $2 \mathrm{~mL}$ of ferric chloride. The mixture was incubated at room temperature for 10 minutes and then the absorbance was measured at 562 $\mathrm{nm}$. A blank was also prepared by replacing $\mathrm{FeCl}_{3}$ and phenanthroline with distilled water.

\section{Statistical analysis}

All data are presented as mean \pm standard error of the mean (SEM). Data obtained were analyzed using one-way ANOVA and student's t-test for differences between groups using SPSS software (IBM, version 20). The level of significance was accepted at the level of $p<0.05$.

\section{RESULTS}

\section{Phytochemical screening of ethanol leaf extract of Sphenocentrum jollyanum}

Preliminary phytochemical screening of $S$. jollyanum as shown in Table 1 revealed the presence of alkaloids, saponin, tannins, phlobatannins, flavonoids and cardiac glycosides.

\section{DPPH scavenging activity}

The DPPH radical scavenging activity of $S$. Jollyanum leaf extract showed a decrease in percentage inhibition of free radical in comparison to ascorbic acid $(\mathrm{p}<0.05)$ (Figure 1). Furthermore, the DPPH radical scavenging activity was significantly increased in a dose-dependent manner $(p<0.05)$ (Figure 1). The lowest extract concentration showed the least DPPH radical scavenging activity while the highest extract concentration exhibited the highest activity (Figure1). The results also revealed that the concentration of $S$. Jollyanum leaf extract required to scavenge the initial DPPH radical concentration by 50 percent ( $\mathrm{IC}_{50}$ value) was $164.214 \mathrm{mg} / \mathrm{mL}$, whereas the $\mathrm{IC}_{50}$ value of the standard compound, ascorbic acid was $248.081 \mathrm{mg} / \mathrm{mL}$ (Table 2).

\section{Total phenolic and flavonoid content of ethanol leaf extract of $S$. jollyanum}

Phenolic compounds are important plant constituents with redox properties responsible for antioxidant activity. The total phenolics content of $S$. Jollyanum leaf extract was determined using spectrophotometric analysis with FolinCiocalteu's phenolic reagent. The TPC radical scavenging activity of $S$. Jollyanum leaf extract showed an increase in phenolic content of free radical in comparison to gallic acid $(p<0.05)$ (Figure 2$)$. Moreover, the TPC activity was significantly increased in a dose-dependent manner $(p<0.05)$ (Figure 2). The highest extract concentration exhibited the highest activity while the lowest extract concentration showed the least phenolic radical scavenging activity. The results also revealed that the 
Table 1. phytochemical constituents of Sphenocentrum jollyanum leaves extract.

\begin{tabular}{lllc}
\hline Phytochemicals & Name of the test & Observation & Result \\
\hline Alkaloids & Dragendorf's Test & Creamy precipitates & +++ \\
Saponins & Frothing test & Appearance of froth & + \\
Tannins & Ferric Chloride Test & blue-black precipitate & ++ \\
Phlobatannins & Hydrochloric Acid Test & red coloured precipitate & + \\
Flavonoids & Shinoda Reduction Test & orange colour & ++ \\
Cardiac glycosides & Salkowski's Test & reddish-brown colour at the interface & ++ \\
\hline
\end{tabular}

Key: $+=$ Present in a trace concentration, $++=$ Present in a medium concentration, $+++=$ Present in a high concentration .

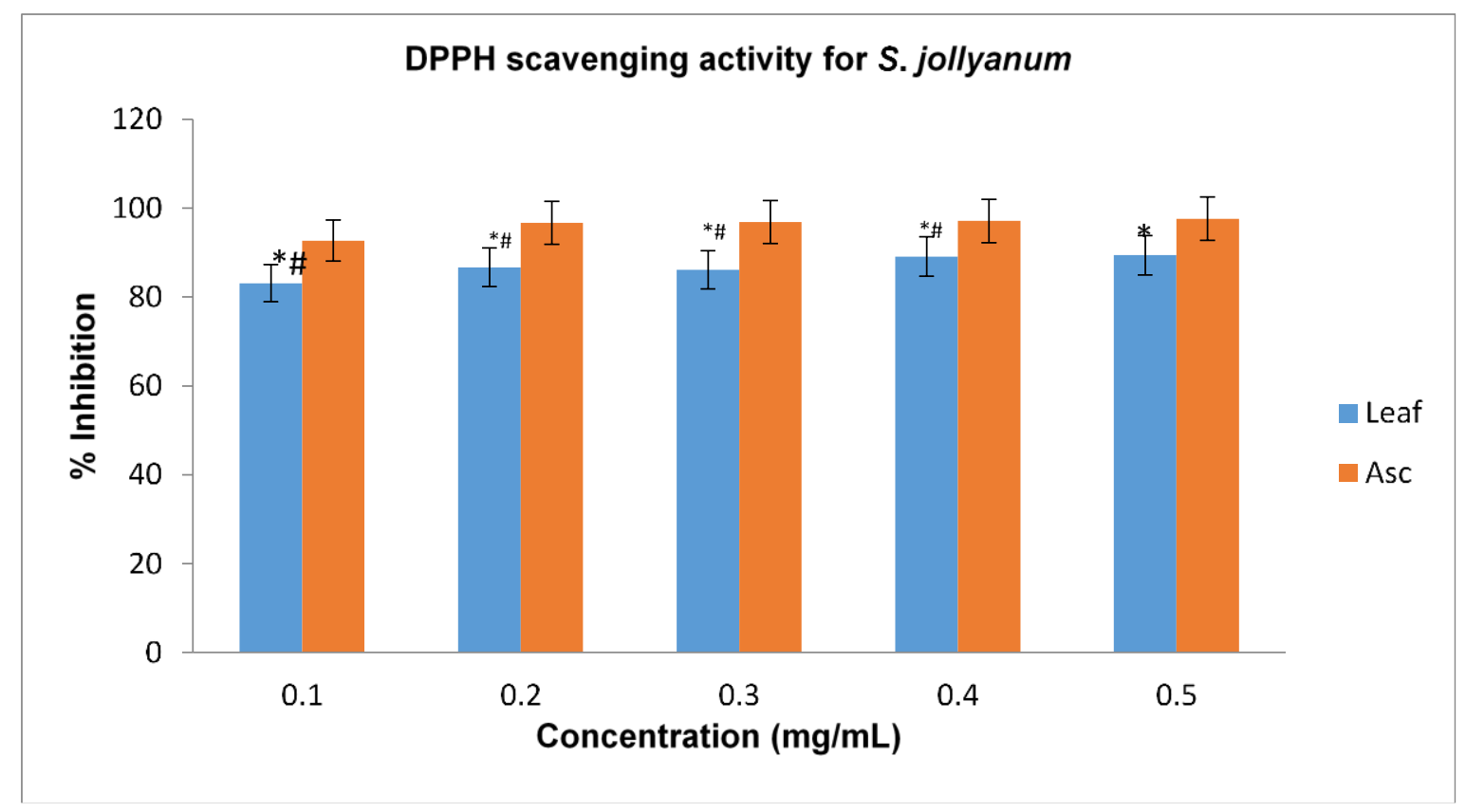

Figure 1. DPPH radical scavenging activity of Sphenocentrum jollyanum leaf extract and ascorbic acid. *compared to Asc; \# is compared to 0.5 concentration; Asc = ascorbic acid; leaf = ethanol leaf extract.

Table 2. IC 50 values of Sphenocentrum jollyanum

\begin{tabular}{lccc}
\hline Sample & $\begin{array}{c}\text { DPPH radical scavenging } \\
\left(\mathbf{I} \mathbf{C}_{\mathbf{5}} \mathbf{~ m g} / \mathbf{m L}\right)\end{array}$ & FRAP $\left(\mathbf{I C}_{50} \mathbf{~ m g} / \mathbf{m} / \mathbf{L}\right)$ & Iron Chelating $\left(\mathbf{I C}_{50} \mathbf{~ m g} / \mathbf{m L}\right)$ \\
\hline Leaf extract & 164.214 & 72.410 & 167.202 \\
Ascorbic acid & 248.081 & 155.134 & 270.703 \\
\hline
\end{tabular}

concentration of $S$. Jollyanum leaf extract required to scavenge the TPC radical concentration was 31.49 $\mathrm{GAE} / \mathrm{mg}$ (Table 3). On the other hand, the total flavonoids contents were determined by using a calibration curve of gallic acid. The results obtained suggest a significantly increase in a dose-dependent manner $(p<0.05)$ (Figure 2). The result of the TFC in S. jollyanum leaf extract was 29.98 GAE/mg (Table 3).

\section{Ferric reducing antioxidant power of ethanol leaf extract of $S$. jollyanum}

The ferric reducing antioxidant power assay of $S$. jollyanum ethanol leaf extract showed that the leaf extracts had a reducing power in comparison to ascorbic acid $(p<0.05)$ (Figure 3$)$. In addition, the reducing activity was significantly increased in a dose-dependent manner 


\section{Flavonoid and phenolic activities of Sphenocentrum Jollyanum}

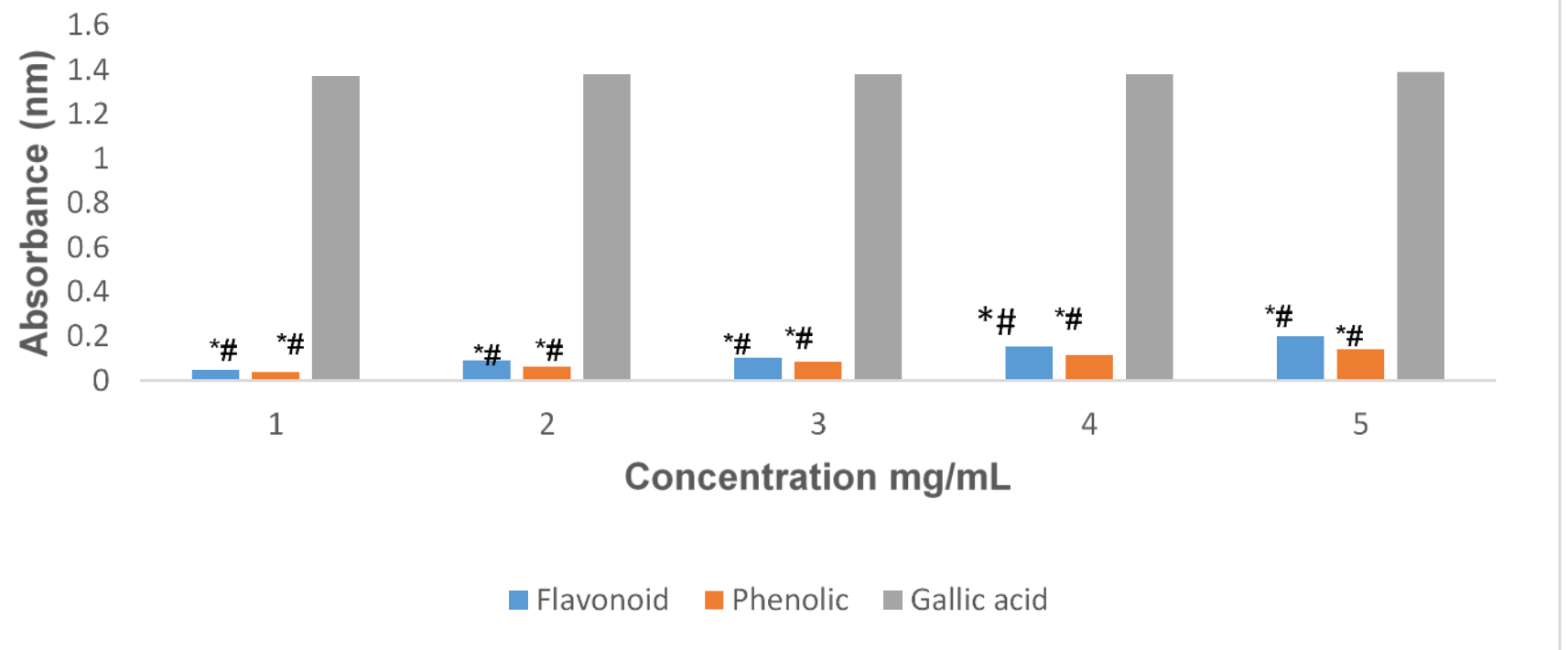

Figure 2. Flavonoid and phenolic activities of Sphenocentrum jollyanum leaf extract and gallic acid. *compared to Gallic acid; \# is compared to 0.5 concentration.

Table 3. Total phenolic and flavonoid content of ethanol extract of Sphenocentrum jollyanum

\begin{tabular}{lcc}
\hline Phytochemicals & Regression equation & Content GAE/g \\
\hline Total phenolic & $\mathrm{R}^{2}=0.9963$ & 31.49 \\
Total flavonoid content & $\mathrm{R}^{2}=0.8626$ & 29.98 \\
\hline
\end{tabular}

$(p<0.05)$ (Figure 3). The lowest extract concentration showed the least FRAP antioxidant activity while the highest extract concentration exhibited the highest activity (Figure 3).

\section{Iron chelating assay of ethanol leaf extract of $S$. jollyanum}

The iron chelating activity of the $S$. jollyanum leaf extract showed the potential to inhibit the formation of iron (II) ferrozine complex in comparison to ascorbic acid $(p<0.05)$ (Figure 4). Additionally, the Iron chelating activity was significantly increased in a dose-dependent manner $(p<0.05)$ (Figure 4). The highest extract concentration demonstrated a higher activity than those of the lower extract concentrations $(p<0.05)$. Furthermore, it was observed that the $\mathrm{IC}_{50}$ value of the $S$. jollyanum leaf extract was $167.202 \mathrm{mg} / \mathrm{mL}$, whereas the $\mathrm{IC}_{50}$ value for the standard, ascorbic acid was $270.703 \mathrm{mg} / \mathrm{mL}$ (Table 2).

\section{DISCUSSION}

Plants have been an essential part of human society since the start of civilization. In the early days of medicine, plants were used for curing many diseases (Huffman, 2001). It is also known to contain in any of their organs, substances (such as alkaloids, tannins, saponin, phenol, and thiol) that can be used for therapeutic purposes or as precursors for the synthesis of useful drugs (Sofowora, 1982). Plants are potential sources of natural antioxidants. Most of the vegetables have been shown in epidemiological studies to be protective against several chronic diseases associated with ageing such as cancer, cardiovascular diseases, cataract and brain and immune dysfunction (Block et al., 1992). These protective effects have been attributed to various compounds such as carotenoids, vitamins $C$ and $\mathrm{E}$ and the phenolic and thiol compounds among other secondary metabolites (Paganga et al., 1999). Sphenocentrum jollyanum are known to play a prominent role in the treatment of diseases as it has been reported to 


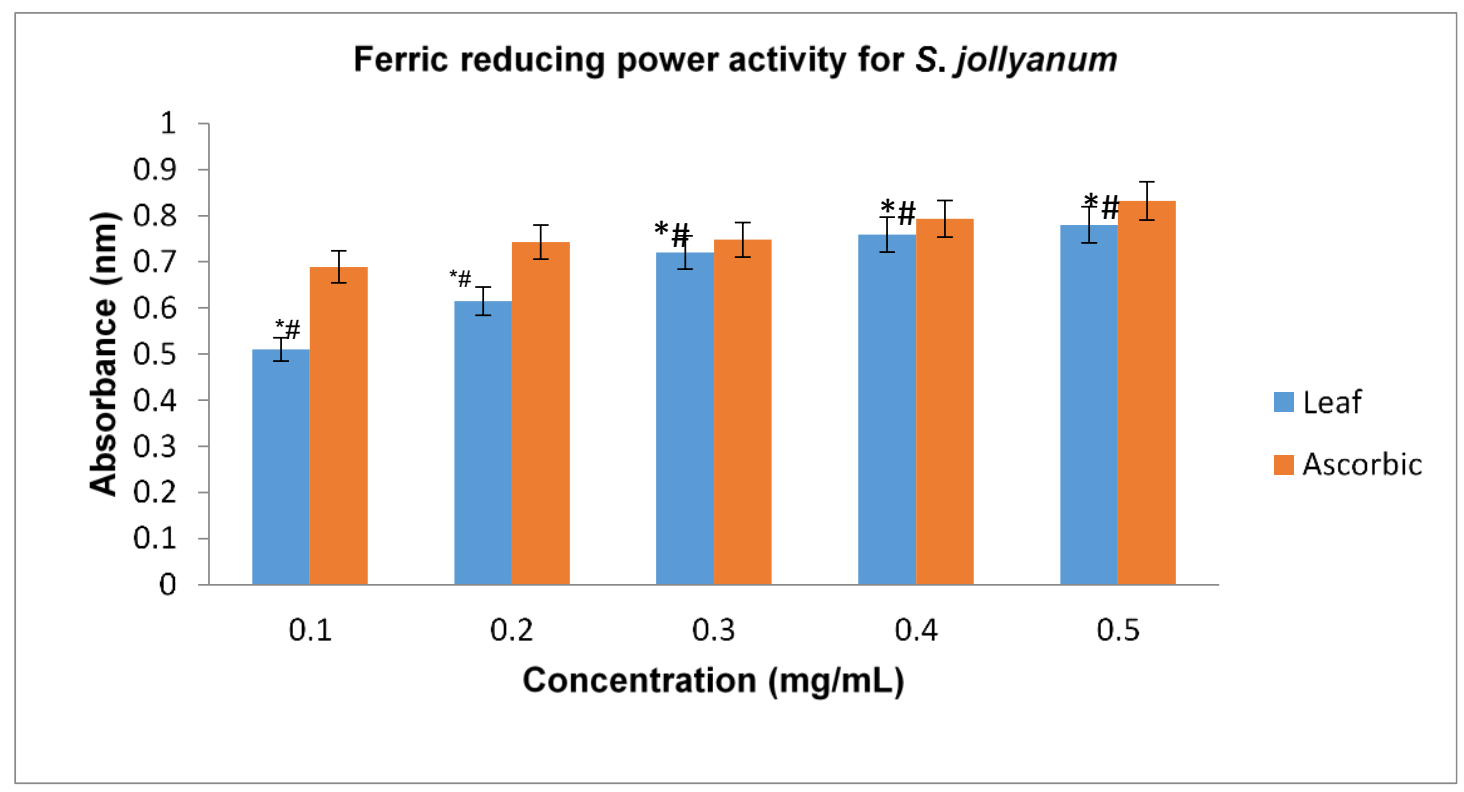

Figure 3. Ferric reducing activity of Sphenocentrum jollyanum leaf extract and ascorbic acid. *compared to Ascorbic; \# is compared to 0.5 concentration; Leaf = ethanol leaf extract.

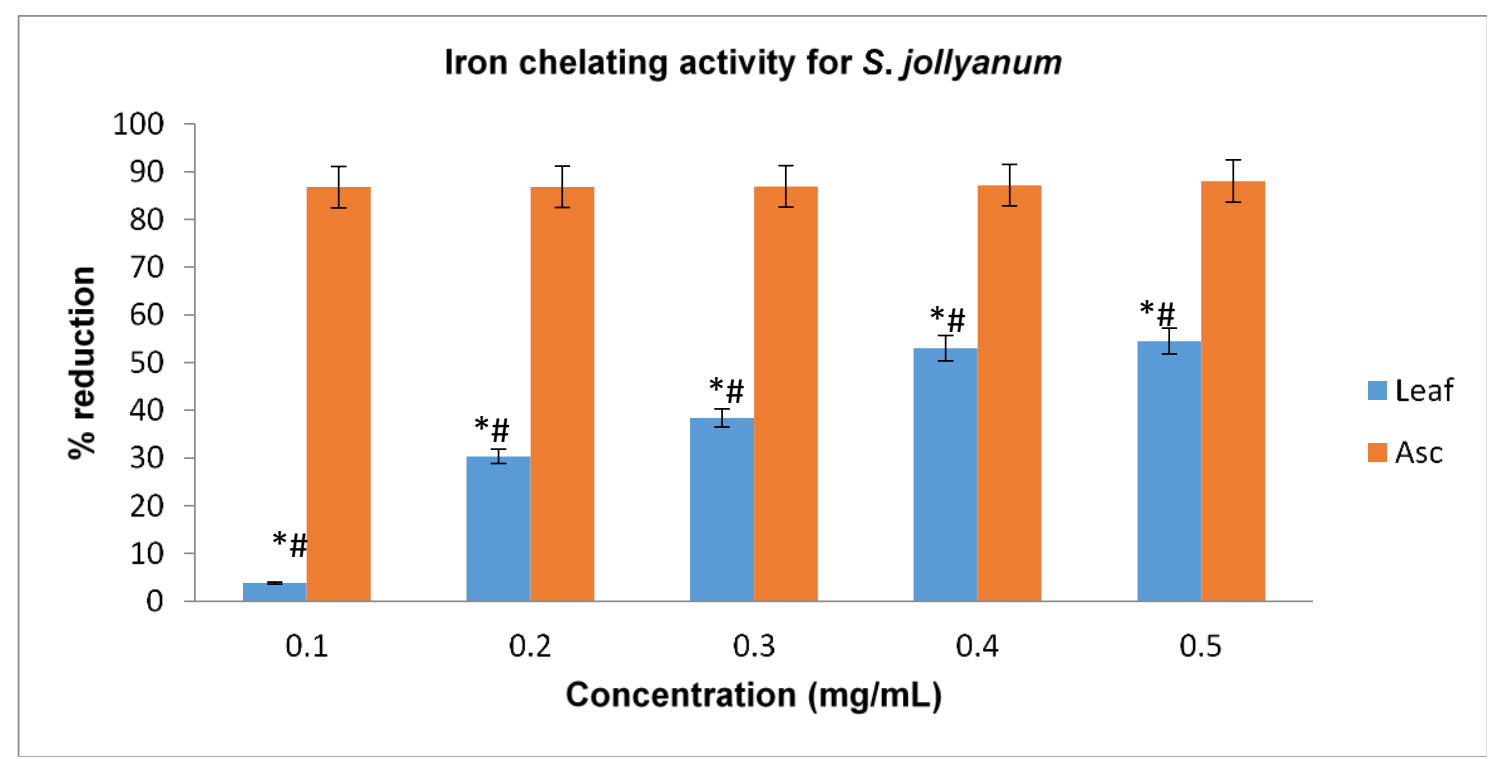

Figure 4. Iron-chelating activity of Sphenocentrum jollyanum leaf extract and ascorbic acid. *compared to Asc; \# is compared to 0.5 concentration; Asc = ascorbic acid; Leaf = ethanol leaf extract.

possess antihypertensive, antioxidant, anti-nociceptive, antiviral, anti-angiogenic effects in animals, and also used against chronic coughs, worms and other inflammatory conditions as well as tumours (Nia et al., 2004; Kayode et al., 2009).

Preliminary phytochemical analysis revealed that the leaf extract of $S$. jollyanum contains alkaloids, tannins, saponins, flavonoids and cardiac glycosides. These plant phytochemicals play important preventive activities mainly as anticancer, antidiarrheals, antioxidant, anti-parasitic, antiviral, antidiabetic, antibacterial, anti-inflammatory, antimicrobial, anti-aging, antidepressant, and wound healing (Athanasiadou et al., 2001; Grujić-Vasić et al., 1986; Kang et al., 2011; Bahramsoltani et al., 2014). It is also reported that leaves containing these phytochemicals help in hypocholesterolemic, immunostimulant, and 
Uka et al.

Table 4. The effect of ethanol extract of Sphenocentrum jollyanum leaf on body weight of mice.

\begin{tabular}{lcccc}
\hline Experiment & $\begin{array}{c}\text { Dose } \mathbf{( m g / k g} \text { body } \\
\text { weight) }\end{array}$ & $\begin{array}{c}\text { Mean weight } \mathbf{( g )} \\
\text { before administration }\end{array}$ & $\begin{array}{c}\text { Mean weight }(\mathbf{g}) \\
\text { after 24hrs }\end{array}$ & \% change \\
\hline \multirow{3}{*}{ Phase 1} & $1000 \mathrm{mg} / \mathrm{kg}$ & $17.74 \pm 0.49$ & $18.45 \pm 0.41$ & $3.87 \pm 0.58$ \\
& $2000 \mathrm{mg} / \mathrm{kg}$ & $19.2^{*} \pm 0.23$ & $20.05 \pm 0.29$ & $3.97 \pm 0.15$ \\
& $3000 \mathrm{mg} / \mathrm{kg}$ & $18.77 \pm 0.16$ & $19.67 \pm 0.17$ & $4.05 \pm 0.09$ \\
Control & & & & \\
& Distilled water & $17.47 \pm 0.47$ & $18.00 \pm 0.37$ & $2.60 \pm 0.23$ \\
& & & & \\
Phase 2 & $3500 \mathrm{mg} / \mathrm{kg}$ & $19.47 \pm 0.09$ & $21.00 \pm 0.64$ & $4.17 \pm 0.37$ \\
& $4500 \mathrm{mg} / \mathrm{kg}$ & $19.79 \pm 0.15$ & $20.29 \pm 0.46$ & $4.21 \pm 0.23$ \\
\hline
\end{tabular}

Values in the same rows are significant at $(p>0.05)$.

anticarcinogenic properties and are believed to lower the risk of cancer and other chronic diseases in humans (Ros, 2000; Hostanska et al., 2005). They also have a great role in stress tolerance of plants and the accumulation of many important bioactive compounds in fruits and vegetables. The alkaloids, cardiac glycosides, tannins and saponins compounds are believed to be responsible for most of these activities which justifies the use of $S$. jollyanum leaf in traditional medicine.

Acute toxicity studies are very vital in understanding the toxicity profiles of plant extracts (Özbek et al., 2004). In the present study, the result of the acute oral toxicity of the ethanol leaf extract of $S$. jollyanum on albino mice revealed the $L_{50}$ to be beyond $4743.42 \mathrm{mg} / \mathrm{kgbw}$ as the experimental mice tolerated the extract with no symptom of acute toxicity (no mortality, skin changes, aggressiveness, diarrhoea, restiveness, seizures, dizziness, weakness, or withdrawal from either food or water) even at higher doses of the extract. The extract caused a significant increase $(p<0.05)$ in body weight of the mice that received ethanol extract of $S$. Jollyanum leaves at all doses when compared with the negative control group, hence showed relative safety of the extract on the mice (Table 4). This result collaborates with earlier scientific publications that suggested a significant $(p<0.05)$ increase in weight gain in Wistar mice treated with the leaf and root extracts of $S$. Jollyanum. (Olorunnisola and Afolayan, 2013; Mbaka et al., 2011).

Plant phenols are groups of natural products with a variable structure that are well known for their beneficial effects on health possess significant antimicrobial and antioxidant activities (Prashith et al., 2010; Sahu and Mahato, 1994). This antioxidant activity of phenolics is mainly due to their redox properties which allow them to act as reducing agents, hydrogen donors and singlet oxygen quenchers (Paganga et al., 1996). According to multiple reports in the literature, phenolic compounds exhibit free radical inhibition, peroxide decomposition, metal inactivation or oxygen scavenging in biological systems and prevent oxidative disease burden (Babbar et al., 2015). The results of the correlation coefficient of total phenolic content and total flavonoid content showed a linear correlation as the concentration of $S$. jollyanum increases. The ethanol extract of $S$. jollyanum leaves has shown to possess flavonoids, which are among the most common bioactive compounds found in medicinal plants (Pietta, 2000).

To evaluate the scavenging effect of the extract in this study, DPPH reduction was investigated against positive control ascorbic acid. The DPPH-stable free radical method is a sensitive way to determine the antioxidant activity of plant extracts (Koleva et al., 2002; Kumar et al., 2008). The odd electron in the DPPH free radical gives a strong absorption maximum at $517 \mathrm{~nm}$ and is purple in colour (Sarla et al., 2011). The colour change from purple to yellow determines the antiradical power of an antioxidant. The resulting decolourization is stoichiometric with respect to the number of electrons captured. The more antioxidants occurred in the extract, the more DPPH reduction occurs. From the result, the $S$. jollyanum leaf extract showed a gradual increase within a dose-related manner. The DPPH radical scavenging activity of the extract varied from 83.1 to $89.4 \%$. This showed that the leaf of $S$. jollyanum possesses free radical scavenging potential. The high percentage inhibition is an indication of a high DPPH free radical scavenging activity.

The ferric reducing power activity is often used to evaluate the ability of an antioxidant to donate an electron (Prior et al., 2005). This assay is based on the ability of antioxidants to reduce $\mathrm{Fe}^{3+} /$ ferricyanide complex to $\mathrm{Fe}^{2+/ f e r r o u s ~ f o r m ~(M e i r ~ e t ~ a l ., ~ 1995) . ~ T h e ~ r e d u c t i o n ~ o f ~ f e r r i c ~}$ cyanide complex $\left(\mathrm{Fe}^{3+} /(\mathrm{CN}-)_{6}\right.$ to the ferrous cyanide form $\left(\mathrm{Fe}^{2+} / \mathrm{CN}-\right)_{6}$ is an indicator that the extract has an electrondonating ability (Farhan et al., 2012). The results obtained in this study showed that the ferric reducing capacity of $S$. Jollyanum increases with increase in concentration between 0.51 to $0.78 \mathrm{mg} / \mathrm{mL}$. It can therefore infer that the reductive ability of the $S$. Jollyanum leaf extract is in a 
dose- dependent manner.

Antioxidants are regarded as good chelator. Phenanthroline quantitatively forms complexes with $\mathrm{Fe}^{2+}$ to form Fe-O-phenanthroline complex, which is a red chromogen. However, in the presence of a chelating agent, it cannot bind to the ferrous ion and this leads to decrease in the absorbance of the extract mixture (Alam et al., 2013). From this study, ethanol extract of $S$. Jollyanum leaf showed a dose - dependent metal chelating activity with percentage chelating activity between 3.82 to $54.5 \%$. This high percentage chelating activity showed that the extract has a high affinity to chelate metals.

The antioxidant capacity of phytochemicals in a biological systems depends on their ability to scavenge radicals, chelate metals, activate the antioxidant enzymes and to inhibit the oxidases (Kulkarni et al., 2004). In this study, $S$. jollyanum leaf extracts showed that it has the ability to scavenge radicals, reduce and chelate metals. Furthermore, the extract has a high content of phenol and flavonoid. It can therefore infer that the antioxidant activity of the extract might be due to the phenolic and flavonoid contents. Similarly, Nia et al. (2004) documented that the antioxidant capacities of medicinal plants are due to their phenolic and flavonoid contents. Many epidemiological studies have shown that the consumption of leafy plant vegetables containing phenolic and flavonoid compounds is associated with a lower incidence of cardiovascular diseases, cancer, diabetes and neurodegenerative diseases as a result of their antioxidant property (Le Marchand, 2002; Adebooye et al., 2008; Jiang et al., 2010). The antioxidative properties of flavonoids are due to numerous dissimilar mechanisms, including the chelation of metal ions, such as iron and copper; the scavenging of free radicals; and the inhibition of enzymes responsible for free radical generation (Benavente et al., 1997).

\section{Conclusion}

The findings of this study indicated that the ethanol extract of Sphenocentrum jollyanum leaves might be a promising antioxidant agent containing phytochemicals. The presence of alkaloids, saponins, tannins, phlobatannins, flavonoids, and cardiac glycosides present in the extracts may be responsible for the antioxidant activity. Future study will isolate and identify the specific compound(s) responsible for the antioxidant activity and the mechanism of action.

\section{CONFLICT OF INTEREST}

The authors declare that there are no potential conflicts of interest.

\section{REFERENCES}

Abbiw, D. K. (1990). Useful plants of Ghana: West African uses of wild and cultivated plants. Intermediate Technology Publications and Royal Botanic Gardens Kew, London, p. 337.

Adebooye, O. C., Vijayalakshmi, R., \& Singh, V. (2008). Peroxidase activity, chlorophylls and antioxidant profile of two leaf vegetables (Solanum nigrum L. and Amaranthus cruentus L.) under six pretreatment methods before cooking. International Journal of Food Science and Technology, 43(1), 173-178.

Alam, M. N., Bristi, N. J., \& Rafiquzzaman, M. (2013). Review on in vivo and in vitro methods evaluation of antioxidant activity. Saudi Pharmaceutical Journal, 21(2), 143-152.

Amidu, N., Woode, E., Owiredu, K. B. A. W., Asare, A. G., Boateng, A. K., \& Opoku-Okrah, C. (2008). An evaluation of toxicity and mutagenicity of Sphenocentrum jollyanum. International Journal of Pharmacology, 4(2), 67-97.

Amidu, N. (2008). An evaluation of the central and sexual behavioral effects and toxicity of the root extract of Sphenocentrum jollyanum Pierre (Menispermaceae). Ph.D. Thesis, Department of Molecular Medicine, Kwame Nkrumah University of Science \& Technology, Kumasi, Ghana.

Athanasiadou, S., Kyriazakis, I., Jackson, F., \& Coop, R. L. (2001). Direct anthelmintic effects of condensed tannins towards different gastrointestinal nematodes of sheep: in vitro and in vivo studies. Veterinary parasitology, 99(3), 205-219.

Bahramsoltani, R., Farzaei, M. H., \& Rahimi, R. (2014). Medicinal plants and their natural components as future drugs for the treatment of burn wounds: an integrative review. Archives of Dermatological Research, 306(7), 601-617.

Benavente-García, O., Castillo, J., Marin, F. R., Ortuño, A., \& Del Río, J. A. (1997). Uses and properties of citrus flavonoids. Journal of Agricultural and Food Chemistry, 45(12), 4505-4515.

Block, G., Patterson, B., \& Subar, A. (1992). Fruit, vegetables, and cancer prevention: a review of the epidemiological evidence. Nutrition and Cancer, 18(1), 1-29.

Burns, M. M. (2000). Alternative medicine: herbal preparations. Clinical Pediatric Emergency Medicine, 1(3), 186-190.

Dinis, T. C., Madeira, V. M., \& Almeida, L. M. (1994). Action of phenolic derivatives (acetaminophen, salicylate, and 5aminosalicylate) as inhibitors of membrane lipid peroxidation and as peroxyl radical scavengers. Archives of Biochemistry and Biophysics, 315(1), 161-169.

Farhan, H., Malli, F., Rammal, H., Hijazi, A., Bassal, A., Ajouz, N., \& Badran, B. (2012). Phytochemical screening and antioxidant activity of Lebanese Eryngium creticum L. Asian Pacific Journal of Tropical Biomedicine, 2(3), S1217-S1220.

Grujić-Vasić, J., Bosnić, T., \& Jovanović, M. (1986). The examining of isolated tannins and their astringent effect. Planta Medica, 52(06), 548-548.

Harborne, J. B. (2005). Phytochemical methods. A guide to modern techniques of plant. Springer (India) Pvt. Ltd. p. 17.

Hostanska, K., Nisslein T., Freudenstein J., Reichling J., Saller, R. (2005). Apoptosis of human prostate androgen-dependent and-independent carcinoma cells induced by an isopropanolic extract of black cohosh involves degradation of cytokeratin (CK) 18. Anticancer research, 25(1A), 139-147.

Hu, S., Yin, J., Nie, S., Wang, J., Phillips, G. O., Xie, M., \& Cui, S. W. (2016). In vitro evaluation of the antioxidant activities of 
carbohydrates. Bioactive Carbohydrates and Dietary Fibre, 7(2), 19-27.

Huffman, M. A. (2001). Self-medicative behavior in the African great apes: An evolutionary perspective into the origins of human traditional medicine: In addition to giving us a deeper understanding of our closest living relatives, the study of great ape self-medication provides a window into the origins of herbal medicine use by humans and promises to provide new insights into ways of treating parasite infections and other serious diseases. BioScience, 51(8), 651-661.

Irvine, F. R. (1961). Woody plants of Ghana (1st edition). Oxford University Press, London. p. 890.

Jiang, H., Ma, Y., Chen, X., Pan, S., Sun, B., Krissansen, G. W., \& Sun, X. (2010). Genistein synergizes with arsenic trioxide to suppress human hepatocellular carcinoma. Cancer Science, 101(4), 975-983.

Kang, N. J., Shin, S. H., Lee, H. J., \& Lee, K. W. (2011). Polyphenols as small molecular inhibitors of signaling cascades in carcinogenesis. Pharmacology and Therapeutics, 130(3), 310-324.

Kayode, J., Ige, O. E., Adetogo, T. A., \& Igbakin, A. P. (2009). Conservation and biodiversity erosion in Ondo state, Nigeria (3). Survey of plant barks used in native pharmaceutical extraction in Akoko region. Ethnobotanical Leaflets, 13,665667.

Koleva, I. I., Van Beek, T. A., Linssen, J. P., Groot, A. D., \& Evstatieva, L. N. (2002). Screening of plant extracts for antioxidant activity: a comparative study on three testing methods. Phytochemical Analysis, 13(1), 8-17.

Kulkarni, A. P., Aradhya, S. M., \& Divakar, S. (2004). Isolation and identification of a radical scavenging antioxidantpunicalagin from pith and carpellary membrane of pomegranate fruit. Food Chemistry, 87(4), 551-557.

Lee, Y. H., Choo, C., Watawana, M. I., Jayawardena, N., \& Waisundara, V. Y. (2015). An appraisal of eighteen commonly consumed edible plants as functional food based on their antioxidant and starch hydrolase inhibitory activities. Journal of the Science of Food and Agriculture, 95(14), 2956-2964.

Le Marchand, L. (2002). Cancer preventive effects of flavonoids-A review. Biomedicine and pharmacotherapy, 56(6), 296-301.

Lorke, D. (1983). A new approach to practical acute toxicity testing. Archives of Toxicology, 54(4), 275-287.

Mbaka, G. O., Adeyemi, O. O., Ogbonnia, S. O., Noronha, C. C., \& Okanlawon, O. A. (2011). The protective effect of ethanol root extract of Sphenocentrum jollyanum on the morphology of pancreatic beta cells of alloxan challenged rabbits. Journal of Morphological Sciences, 28(1), 37-45.

Mbaka, G. O, Adeyemi, O. O., Noronha, C. C., Anunobi, C. C., \& Okanlawon, A. O. (2009). Anti- hyperglycaemic and hypoglycaemic effects of ethanol root extract of Sphenocentrum jollyanum in normal and alloxan-induced diabetic rabbits. Brazilian Journal of Morphology Science, 26(2), 123-127.

Meir, S., Kanner, J., Akiri, B., \& Philosoph-Hadas, S. (1995). Determination and involvement of aqueous reducing compounds in oxidative defense systems of various senescing leaves. Journal of Agricultural and Food Chemistry, 43(7), 1813-1819.

Muko, K. N., Ohiri, P. C., \& Ezugwu, C. O. (1998). Antipyretic and analgesic activities of Sphenocentrum jollyanum. Nigeria Journal of Natural Products and Medicine, 2(12),52-53.
Nia, R., Essien, E. E., lyadi, K. C., Bassey, A. I. L., Antai, A. B., \& Franz, G. (2004). Evaluation of the anti-oxidant and antiangiogenic effects of Sphenocentrum Jollyanumpierre. African Journal of Biomedical Research, 7(8),129-132.

National Institute of Health (2015). Public health service policy on human care and use of laboratory animals. OLAW.nih.gov.

Babbar, N., Oberoi, H. S., \& Sandhu, S. K. (2015). Therapeutic and nutraceutical potential of bioactive compounds extracted from fruit residues. Critical Reviews in Food Science and Nutrition, 55(3), 319-337.

Oliver-Bever, B. (1986). Medicinal plants in tropical West Africa. Cambridge University Press, Cambridge, United Kingdom. p.375.

Olorunnisola, O. S., \& Afolayan, A. J. (2013). In vivo antioxidant and biochemical evaluation of Sphenocentrum jollyanum leaf extract in P. berghei infected mice. Journal of Pharmaceutical. Sciences, 26(3), 445-450.

Özbek, H., Öztürk, M., Öztürk, A., Ceylan, E., \& Yener, Z. (2004). Determination of lethal doses of volatile and fixed oils of several plants. Eastern Journal of medicine, 9(1), 4-6.

Paganga, G., Miller, N., \& Rice-Evans, C. (1999). The phenolic content of fruits and vegetables and their antioxidant activities: What does a serving constitute? Free Radical Research, 30(2), 153-162.

Paganga, G., Miller, N., \& Rice-Evans, C. (1996). Structureantioxidant activity relationships of flavonoids and phenolic acids. Free Radical Biology and Medicine. 20(7), 933-956.

Pietta, P. G. (2000). Flavonoids as antioxidants. Journal of natural products, 63(7), 1035-1042.

Prashith, K. T. R., Vinayaka, K. S., Soumya, K. V., Ashwini, S. K., Kiran, R. (2010). Antibacterial and antifungal activity of methanolic extract of Abrus pulchellus wall and Abrus precatorius Linn- A comparative study. International Journal of Toxicological and Pharmacological Research, 2(1), 26-29.

Nayak, P., Nayak, S., Kar, D. M., \& Das, P. (2010). Pharmacological evaluation of ethanolic extracts of the plant Alternanthera sessilis against temperature regulation. Journal of Pharmacy Research, 3(6), 1381-1383.

Prior, R. L., Wu, X., \& Schaich, K. (2005). Standardized methods for the determination of antioxidant capacity and phenolics in foods and dietary supplements. Journal of Agricultural and Food Chemistry, 53(10), 4290-4302.

Repon, K. S., Srijan, A., Syed, S. H. S., \& Priyanka, R. (2013). Medicinal activities of the stem bark of Musa sapientum var. Sylvesteris in-vitro. Asian Pacific Journal of Tropical Biomedicine, 3(6), 476-482.

Ros, E. (2000). Intestinal absorption of triglyceride and cholesterol. Dietary and pharmacological inhibition to reduce cardiovascular risk. Atherosclerosis, 151(2), 357-379.

Sahu, N. P., \& Mahato, S. B. (1994). Anti-inflammatory triterpene saponins of Pithecellobium dulce: characterization of an echinocystic acid bisdesmoside. Phytochemistry, 37(5), 14251427.

Sandhya, B., Thomas, S., Isabel, W., \& Shenbagarathai, R. (2006). Ethnomedicinal plants used by the Valaiyan community of Piranmalai hills (reserved forest), Tamilnadu, India - A pilot study. African Journal of Traditional, Complementary and Alternative Medicines, 3(1), 101-114.

Sarla, S., Prakash, M. A., Apeksha, R., Subhash, C. (2011). Free radical scavenging (DPPH) and ferric reducing ability (FRAP) of Aphanamixis polystachya (Wall) Parker. International Journal of Drug Development and Research, 3(4), 271-274. 
Schippmann, U., Leaman, D., \& Cunningham, A. (2002). Impact of cultivation and gathering of medicinal plants on biodiversity: Global trends and issues. FAO, Rome, Italy.

Sofowora, A. (1982). Medicinal plant in traditional medicine in West Africa. First Edition. John Willy and Sons London.

Kumar, P. S., Sucheta, S., Deepa, V. S., Selvamani, P., \& Latha, S. (2008). Antioxidant activity in some selected Indian medicinal plants. African Journal of Biotechnology, 7(12), 1826-1828.

Tiwari, A. K., \& Mehta, R. (2013) Medicinal plants used by traditional healers in Jashpur district of Chhattisgarh India. Life Science Leaflet, 1, 31-41.
Topno, S. C., \& Sinha, M. (2018). Study of medicinal plants used to heal skin diseases by tribes of West Singhbhum district of Jharkhand (India). Journal of Pharmacognosy and Phytochemistry, 7(1), 371-376.

World Health Organization (WHO) (2013). Traditional Medicine Strategy. Geneva: World Health Organization. 2014-2023.

Zhishen, J., Mengcheng, T., \& Jianming, W. (1999). The determination of flavonoid contents in mulberry and their scavenging effects on superoxide radicals. Food Chemistry, 64(4), 555-559. 